\title{
Impact Assessment of Adoption of Improved Varieties of Millet in North Kordofan State Sudan
}

\author{
Salih Elagab Elsheikh ${ }^{1 *}$, Hamid H Faki ${ }^{2}$ and ElRasheed A Fageeri ${ }^{2}$ \\ ${ }^{1}$ Associate Research Professor,Elobeid Research Station, Sudan \\ ${ }^{2}$ Agricultural Economics and policy Research Centre Shambat, Sudan
}

Received: 眥 September 08, 2018; Published: 琒 September 18, 2018

*Corresponding author: Salih Elagab Elsheikh, Associate Research Professor, Elobeid Research Station, Sudan

\begin{abstract}
This study was carried out with the objective to assessment the impacts of adoption of improved varieties of millet on the farm income of households in three localities of Sheikan, Umrawaba and Elrahad in the North Kordofan State. Data for this study was primarily from farm household surveys conducted in seven seasons (2006/2007 to 2014/2015) in three localities of Sheikan, ElRahad and UmRawaba in North Kordofan State. A random sample of 794 households was randomly drawn from different villages in the study area. Multi-stage random approach was adopted. Treatment effect regression was used to assess the impact of adoption of improved varieties in the study area. Analysis was completed using STATA12 and SPSS22 software packages to draw results and test hypotheses.

Factors which positively affected farmers' decision to adoption improved varieties of millet were education (0.016), attending training (0.223), family members male (0.004) and sex of HH (0.198), Income from farm increased by 29727.86 SDG per year as a result of adoption of millet improved varieties. Area of improved varieties would increase by 9.63 Hectare per year as a result of adoption improved varieties of millet.
\end{abstract}

\section{Introduction}

There has been much discussion on the need to increase productivity and sustainability in agriculture globally in the medium to long terms, but much less information is available on specific means to achieve this aim. Increasing agricultural productivity is critical to meet expected rising demand and, as such, it is instructive to examine recent performance in cases of modern agricultural technologies (FAO, 2011). In Sudan, sorghum, millet, groundnut and sesame yields per unit area of land are higher at research level and well managed farms than in typical farmers' fields. The yield gap is mainly attributed to ineffective extension and technology transfer, lack of access to inputs, poor access to finance, and problems related to marketing.

The rain-fed farming sector in Kordofan region has been contributing considerably to the country's annual crop production. It produces about $40 \%$ of the total millet production, $15 \%$ of sorghum, $25 \%$ of groundnut, $30 \%$ of sesame, and $5 \%$ of maize. Other crops grown in the region include roselle, cowpea, and cotton.

\section{Problem Statement}

In general, agricultural production and productivity could be increased by allocation of more resources to agriculture and improvement of agricultural technology which requires more investment in education, health and infrastructure. In the context of Sudan profile, various governments have declared a policy aiming at self-sufficiency in food. The means towards achieving this objective has always been an expansion in cultivated area and/or improvement in yield.

It is no longer possible to meet the needs of increasing numbers of the world population and to achieve food security objectives by expanding areas under cultivation since the fertile land is not increasing over time. But this problem can only be better solved by increasing agricultural productivity of farm households. Still, achieving agricultural productivity growth will not be possible without developing and disseminatingyield-increasing technologies and application of these technologies by farm households. A main 
feature of farming in North Kordofan is continuous deterioration in the natural resources base and production. Such deterioration has resulted from various influential factors, among them are poor genetic resources, biophysical factors including topography, low rainfall, soil quality, insect, diseases. To answer the below key questions, studies are required to be conducted in the area but accessed information does not show that such adoption studies have been conducted in North Kordofan state in general and Sheikan, Elrahad and Umrawaba localities, in particular to identify the determinants the impact of adoption of improved varieties of millet on the farm income.

\section{Objectives of the study}

The overall objective of this study is to measure the impacts of adoption improved varieties on the yields of millet and household income and. The study also aims to achieve the following specific objectives:

a) To identify and analyze socioeconomic factors that influences the adoption of improved varieties of millet among farmers.

b) To understand the factors that determines the adoption and intensity of use of improved varieties of millet.

c) To study the impact of adoption on yield and household incomes.

d) To provide policy makers and related institutions with a clear picture of the impact of adopted improved varieties on the livelihoods of smallholder farmers.

\section{Research hypotheses}

a) Adoption of improved varieties leads to high yields of sorghum and millet.

b) Farmers' perception of technology characteristics significantly affects their adoption decision.

c) Adoption of improved crops varieties leads to higher household income and increase farm income of households.

\section{Data Sample Procedures}

The sampling: Data for this study comes primarily from farm household surveys conducted in seven seasons (2006/2007 to 2014/2015) in three localities: Sheikan, ElRahad and UmRawaba in North Kordofan State. Multi-stage random approach was adopted. The localities were used as a sampling frame. From the three localities we selected nine locality units randomly, from theses nine locality unit eight to twelve villages were randomly selected for conducting interviews for individual households. In each village eight to sixteen household heads, in both male- and female-headed households, were randomly selected for interviews.
Accordingly, a sample of 794 households was randomly drawn from different villages in the study area. Selection was structured on the basis of ensuring a representative sample of male and female household heads. Farmer's household heads were interviewed using questionnaire. Each male and female household heads was interviewed annually for seven seasons. Analysis was undertaken using STATA12 and SPSS22 software packages according to which results, and hypotheses were drawn.

\section{Treatment Effects Regression}

A treatment effect is the average causal effect of a binary $(0-1)$ variable on an outcome variable of scientific or policy interest. The term treatment effect originates in medical literature concerned with the causal effects of binary, yes or no, such as an experimental drug or a new surgical procedure. But the term is now used much more generally. The causal effect of a subsidized training program is probably the mostly widely analyzed treatment effect in economics (see, for example [1] for one of the first examples.

The model assumes a treatment $\mathrm{W}$ is binary with two possible states; W (0) and W (1). For each unit, there are two potential outcomes; Y (0) (the outcome without treatment) and Y (1) (the outcome with treatment). These outcomes can be discrete, continuous, or both.

The Gain from treatment is

$$
Y(1)-Y(0)
$$

For a particular unit I, the gain treatment is

$$
Y i(1)-Y i(0)
$$

If we could observe these gains for a random sample, the problem would be easy: just average the gain across the random sample. The key problem with this model is that for each unit $i$, only one of Yi (0) and Yi (1) is observed and in effect, there is a missing data problem. It assumes a random sample of units from the population, but we do not observe both outcomes.

In the treatment effects regression model, there are two parameters of primary interest:

a) The average treatment effect (ATE) which is the expected gain for a randomly selected unit from the population.
ӥ̈̈и =
(1) -

b) The average treatment effect on the treated (ATT) is the average gain for those who actually were treated:

$$
\text { Tatt }=E[Y(1)-Y(0) \mid W=1)]
$$


With heterogeneous treatment effects - that is, when $Y i$ (1) $Y i(0)$ is not constant the average treatment effect and the average treatment effect on the treated can be very different.

Occasionally it is helpful to define average treatment effects in a sample, for example,

$$
\text { ate }=N^{-1} \Sigma i=1(Y i(1)-Y i(0)
$$

The key assumptions of the treatment effects regression are:

a) Confoundedness; rather than assume random assignment for each unit $i$ a random vector representing the population distribution of covariates $\mathrm{X} i$ is drawn. The strongest form of confoundedness is conditional on $\mathrm{X}$, the counterfactual outcomes are independent of W. For units in the subpopulation defined by $\mathrm{X}=\mathrm{x}$, assignment of treatments is randomized. b) Overlap: for all $\mathrm{x}$ in the support $\mathrm{X}$ of $\mathrm{X}$,

$$
0<P(W=1 \mid X=x)<1
$$

In other words, each unit in the defined population has some chance of being treated and some chance of not being treated. The probability of treatment as a function of $\mathrm{x}$ is known as the propensity score

$$
P \S(\$ \S)=P(W=\mid X=x)
$$

\section{Results and Discussion}

\section{Adoption Rate}

The crop varieties grown by farmers are usually local varieties with very few cases where improved varieties are used in small acreage (Tables 1 \& 2).

Table 1: Average distribution of farmers according to adoption of improved varieties in Sheikan, Um rawaba and Elrahad localities. seasons 2007-2015. Source: Field surveys, 2007-2015.

\begin{tabular}{|c|c|c|c|c|}
\hline \multirow{2}{*}{ Improved varieties } & \multicolumn{2}{|c|}{ Adopter } & \multicolumn{2}{c|}{ Non-adopter } \\
\cline { 2 - 5 } & Freq & Percentage & Freq & 62.7 \\
\hline Sorghum & 209 & 37.7 & 403 & 90.2 \\
\hline Millet & 60 & 9.8 & 550 & Percentage \\
\hline
\end{tabular}

Table 2: Distribution of respondents according to adoption degree of improved varieties of sorghum, millet, and groundnut and sesame $\%$.

\begin{tabular}{|c|c|c|c|c|}
\hline Season & Area grown (Ha) & $\begin{array}{c}\text { Area cultivated with local } \\
\text { seeds (Ha) }\end{array}$ & $\begin{array}{c}\text { Area cultivated with } \\
\text { improved Seeds (Ha) }\end{array}$ & Adoption degree\% \\
\hline $2006-2007$ & 9.25 & 7.67 & 1.57 & 17 \\
\hline $2007-2008$ & 7.47 & 5.98 & 1.76 & 23 \\
\hline $2008-2009$ & 8.27 & 6.57 & 1.71 & 31 \\
\hline $2009-2010$ & 5.74 & 4.1 & 1.7 & 1.35 \\
\hline $2010-2011$ & 7.86 & 6.51 & 3.73 & 39 \\
\hline $2012-2013$ & 9.49 & 5.76 & 2.55 & 44 \\
\hline $2014-2015$ & 8.41 & 5.86 & & \\
\hline
\end{tabular}

Source: Field surveys, 2007-2015.

\section{Preferences of using millet varieties (Table 3)}

Table 3: Farmers preferences of using millet varieties in Sheikan, Umrawaba and Elrahad localities.

\begin{tabular}{|c|c|c|}
\hline Preference of using millet varieties. & Frequency & Percentage \\
\hline Always prefer using Ashana & 28 & 10.6 \\
\hline Sometimes prefer using Ashana & 7 & 2.7 \\
\hline Always prefer using Local varieties & 216 & 82.8 \\
\hline Using what available in market & 9 & 3.4 \\
\hline Sometimes prefer using Local varieties & 3 & 1.1 \\
\hline Total & 263 & 100 \\
\hline
\end{tabular}

Source: Field surveys, 2007-2015. 


\section{Varietal Characteristics}

The farmers state that the improved varieties of millet has better characters than the local varieties, except for the characters taste, color and price Table 4.

Table 4: Millet characteristics in Sheikan, ElRahad and Umrawaba localities 2007/2015.

\begin{tabular}{|c|c|c|c|c|}
\hline Character & $\begin{array}{c}\text { Improved } \\
\text { variety }\end{array}$ & $\begin{array}{c}\text { Local } \\
\text { variety }\end{array}$ & Indifferent & Don't know \\
\hline $\begin{array}{c}\text { Drought } \\
\text { resistance }\end{array}$ & 71.6 & 24.4 & 1 & 2 \\
\hline $\begin{array}{c}\text { Pests } \\
\text { resistance }\end{array}$ & 66.5 & 28.1 & 3.2 & 2.2 \\
\hline $\begin{array}{c}\text { Diseases } \\
\text { resistance }\end{array}$ & 67.5 & 26.6 & 3.2 & 2.7 \\
\hline $\begin{array}{c}\text { Production } \\
\text { in hard } \\
\text { conditions }\end{array}$ & 72.9 & 23.4 & 1.7 & 2 \\
\hline $\begin{array}{c}\text { Early } \\
\text { maturing }\end{array}$ & 78.7 & 19.8 & 1 & 0.5 \\
\hline $\begin{array}{c}\text { Easy to } \\
\text { harvest }\end{array}$ & 64.2 & 24.3 & 10.5 & 1 \\
\hline $\begin{array}{c}\text { Large seeds } \\
\text { size }\end{array}$ & 55 & 41.5 & 3.2 & 0.2 \\
\hline $\begin{array}{c}\text { High } \\
\text { Productivity }\end{array}$ & 65 & 33.3 & 0.7 & 1 \\
\hline Better Taste & 28 & 70.1 & 1.7 & 0.2 \\
\hline Best Colour & 25.2 & 73.6 & 1 & 0.2 \\
\hline High Price & 31.1 & 61.5 & 7.1 & 0.2 \\
\hline $\begin{array}{c}\text { Tillers } \\
\text { production }\end{array}$ & 49.6 & 48.4 & 0.7 & 1.2 \\
\hline
\end{tabular}

Source: Field surveys, 2007-2015.

\section{Impact of Using Improved Varieties of Millet on Farm Income}

The treatment effects regression was used to assess the impacts of using improved varieties of millet on farm income, using improved varieties is the treatment used in the first equation of this model. In the first step it was regressed against different variables which affect the likelihood to adopt improved varieties of millet and was used to estimate impacts in the second step of the treatment effects model (Table 5). For the impact of adoption of improved varieties of millet on farm income, the most important factor which increase the likelihood to adopt improved varieties of millet is attending training $\left(1.847^{* *}\right)$. The effect of variety in the outcome equation (farm income) was significant at 0.01level (Table 5).

Education (829.10), total grown area (96.39), male's family members (1378.64), sex of household head (1486) were the most important factors which increased farm income (Table 5). Income from farm increased by SDG 29727.86 per year as a result of adoption millet improved varieties. This finding agreed with the adoption of improved technologies was expected to enhance productivity and consequently increase incomes, reduce poverty and accordingly ensure equity among beneficiaries [2-4].

Table 5: Estimates of the treatment effects regression on farm income for millet. Symbols *,** and *** indicate significant differences at $0.1,0.05$ and 0.01 levels of significance, respectively.

\begin{tabular}{|c|c|c|c|c|}
\hline & \multicolumn{2}{|c|}{ Variety } & \multicolumn{2}{|c|}{ Income } \\
\hline & Coefficient & SE & coefficient & SE \\
\hline $\begin{array}{l}\text { Farming } \\
\text { experience } \\
\text { (years) }\end{array}$ & -0.036 & 0.054 & & \\
\hline Education & -0.636 & 0.941 & 829.1 & 2806 \\
\hline $\begin{array}{c}\text { Numbers of males } \\
\text { in family }\end{array}$ & 0.113 & 0.247 & 1378.64 & 912.24 \\
\hline $\begin{array}{l}\text { Numbers of } \\
\text { females in family }\end{array}$ & -0.099 & 0.28 & -960.28 & 909.22 \\
\hline $\begin{array}{l}\text { Females Family } \\
\text { labor }\end{array}$ & -0.593 & 0.685 & & \\
\hline Age of $\mathrm{HH}$ & -0.037 & 0.05 & & \\
\hline Total area grown & 0.011 & 0.017 & 96.39 & 66.85 \\
\hline $\begin{array}{l}\text { Area grown with } \\
\text { improved seeds }\end{array}$ & -0.034 & 0.051 & & \\
\hline Sex of $\mathrm{HH}$ & 1.283 & 1.047 & 1486 & 4235.7 \\
\hline $\begin{array}{l}\text { Availability of } \\
\text { improved seeds }\end{array}$ & & & -269.05 & 2465.1 \\
\hline $\begin{array}{c}\text { Knowledge } \\
\text { cultural } \\
\text { operations }\end{array}$ & -6.257 & 646.55 & & \\
\hline Training & $1.847^{* *}$ & .0 .965 & & \\
\hline $\begin{array}{c}\text { Adoption of } \\
\text { improved variety }\end{array}$ & & & $29727.86^{* *}$ & 14622.7 \\
\hline Constant & 6.847 & 645.56 & 2317 & 10783 \\
\hline Wald chi2 & & & 26.05 & \\
\hline Prob $<$ chi2 & & & $0.025^{* * *}$ & \\
\hline Rho & & & -1 & \\
\hline Sigma & & & 13536.59 & \\
\hline $\begin{array}{l}\text { Number of } \\
\text { observations }\end{array}$ & -24276.6 & & 105 & \\
\hline lambda & & 8528.327 & $0.004^{* * *}$ & \\
\hline
\end{tabular}

Area of improved varieties would increase by 9.63 hectare per year as a result of adoption of millet improved varieties. Attending training $\left(0.363^{* *}\right)$, total grown area $\left(0.124^{* * *}\right)$, number of male's family members $\left(0.825^{* * *}\right)$, were the most important factors which increased area of improved varieties, whereas, availability of improved varieties $\left(-2.925^{* * *}\right)$, decreased area of improved varieties Table 6. 
Table 6: Estimates of the treatment effects regression on area of improved varieties for millet.

\begin{tabular}{|c|c|c|c|c|}
\hline & \multicolumn{2}{|c|}{ Variety } & \multicolumn{2}{|c|}{ Area of improved varieties } \\
\hline & Coefficient & SE & coefficient & SE \\
\hline Farming experience (years) & -0.042 & 0.052 & 0.044 & 0.081 \\
\hline Education & -0.489 & 0.825 & -.2 .250 & 1.416 \\
\hline $\begin{array}{c}\text { Knowledge cultural } \\
\text { operations }\end{array}$ & -5.781 & 387.42 & & \\
\hline $\begin{array}{l}\text { Number of males in the } \\
\text { Family }\end{array}$ & 0.032 & 0.222 & $0.825^{* * *}$ & 0.368 \\
\hline $\begin{array}{l}\text { Number of females in } \\
\text { Family }\end{array}$ & -0.161 & 0.25 & 0.223 & 0.363 \\
\hline Age of $\mathrm{HH}$ & -0.034 & 0.045 & -0.079 & 0.072 \\
\hline \multicolumn{5}{|l|}{ Total area grown } \\
\hline $\begin{array}{l}\text { Area grown with improved } \\
\text { seeds }\end{array}$ & 0.007 & 0.019 & $0.124^{* * *}$ & 0.027 \\
\hline Sex of HH & 0.933 & 0.929 & -1.026 & 1.784 \\
\hline $\begin{array}{l}\text { Availability of improved } \\
\text { seeds }\end{array}$ & & & $-2.925^{* * *}$ & 0.981 \\
\hline Training & & & $0.363^{* *}$ & 2.219 \\
\hline Adoption improved variety & & & $9.63^{*}$ & 6.907 \\
\hline Constant & 6.218 & 387.43 & $11.766^{* * *}$ & 4.705 \\
\hline Wald chi2 & & & 99.92 & \\
\hline Prob $<$ chi2 & & & $0.0000^{* * *}$ & \\
\hline Rho & & & -1 & \\
\hline Sigma & & & 5.384119 & \\
\hline Number of observations & & & 106 & \\
\hline lambda & -7.75886 & 4.001954 & $0.053^{*}$ & \\
\hline
\end{tabular}

Symbols *** and *** indicate significant differences at $0.1,0.05$ and 0.01 levels of significance, respectively.

\section{References}

1. Ashenfelter $O$ (1978) Estimating the effect of training programs on earnings. Review of Economics and Statistics 6: 47-57.

2. Asante EG, Appiah MR, Ofori Frimpong K andAfrifa AA (2004) The economics of fertilizer use on some peasant cocoa farms in Ghana. Ghana Journal of Agricultural Science 33: 183-190.
3. FAO (2011) The state of food and Agriculture, Women in agriculture, ISSN 0081-4539 FAO (2012) OECD-FAO Agricultural Outlook, 2012 2021.

4. Shiyani RL, Joshi PK, Asokam M, Bantilan MCS (2002) Adoption of improved Chickpea Varieties: Krishak Bharati Cooperative (KRIBHCO) Experience in tribal region of Gujurat, India. Agricultural Economics 27: 33-39.

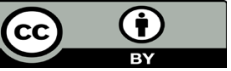

This work is licensed under Creative Commons Attribution 4.0 License

To Submit Your Article Click Here:

Submit Article
DOI: $10.32474 /$ CIACR.2018.04.000193

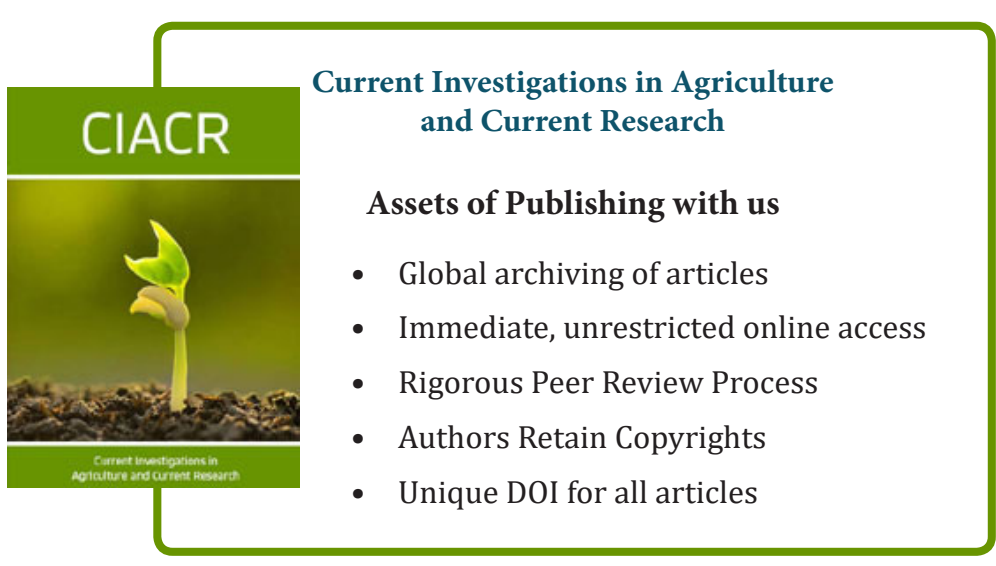

